\title{
Сравнительная характеристика декоративности коры Padus maackii в зависимости от места произрастания в урбанизированной среде города Ижевска
}

\section{Comparative characteristics of Padus maackii biometric indicators depending on the place of growth in the urban environment of the Izhevsk city}

\author{
Кузьмина Н. М. \\ Kuzmina N. M. \\ Удмуртский Федеральный исследовательский центр Уральского отделения Российской академии наук, г. Ижевск, Россия. \\ E-mail:kuzmina1956@mail.ru \\ Udmurt Federal research center of the Ural branch of the Russian Academy of Sciences, Izhevsk, Russia
}

\begin{abstract}
Peферат. В работе приведены данные исследования декоративности коры Padus maackii (Rupr.) Kom. в различных экологических группах насаждений города Ижевска. Приводится характеристика местопроизрастания данных экологических групп. Выявлены периоды с экстремальными климатическими условиями в годы исследований (2012-2015 гг.). Приводится сравнительная характеристика изменения оценки декоративности коры в период 2012-2015 гг. Определены причины ухудшения декоративности насаждений.
\end{abstract}

Ключевые слова. Декоративность коры, характеристика местопроизрастания, экологические группы, Padus maackii.

Summary. The data on examine of the bark decorativeness of Padus maackii (Rupr.) Kom. in various ecological groups of plantings in Izhevsk are presented in the article. The characteristic of these ecological groups' place of growth is given. The periods with extreme climatic conditions in the years of research (2012-2015) are revealed. The comparative analysis of changes of the bark decorativeness evaluation during 2012-2015 have been made. The causes of deterioration of the plantings' decorativeness were identified.

Key words. Characteristics of habitat, bark decorativeness, ecological groups, Padus maackii.

Декоративность древесных растений - сложный комплексный показатель, обусловленный степенью проявления и гармоничностью сочетания многих признаков. К ним, в первую очередь, относят форму и конструкцию кроны, окраску ствола и ветвей, привлекательность цветения и плодоношения, осеннюю окраску листьев и многое другое. Padus maackii (Rupr.) Kom. - черемуха Маака - является очень привлекательным видом. Ствол Padus maackii покрыт нарядной, красновато-оранжевой или золотисто-желтой корой, гладкой, блестящей, отслаивающейся поперек ствола бумагообразными, тонкими пленками. Благодаря этому черемуха Маака сохраняет свою декоративность даже в зимний период. Такой кора становится только на свету.

Проведенные многочисленные исследования в городах Сибири и Урала отмечают, что Padus maackii обладает высокими санитарно-гигиеническими и декоративными свойствами. (Усенко, 1984; Семкина и др., 1991; Коропачинский, Встовская, 2002; Иншаков, Сунцова, 2007; Сафронова, 2009; Сунцова, Иншаков, 2017). Padus maackii занимает в озеленении города Ижевска 0,3 \% от доли видового состава. Встречается в дворовых насаждениях, в магистральных посадках, редко - в скверах и парках города Ижевска.

Нами было проведено исследование декоративных свойств Padus maackii в разных экологических группах насаждений г. Ижевска, оценивалось качество шести основных декоративных свойств че- 
ремухи: цвет коры, общий габитус, цветение, форма кроны, цвет и качество листвы, осенняя расцветка. Для оценки качества исследуемых декоративных свойств нами была разработана шкала по пятибалльной системе по каждому декоративному признаку. В течение года каждое дерево оценивалось визуально по разработанной шкале, конкретно по каждому из шести основных декоративных свойств (Кузьмина, Федоров, 2013).

Для исследований было выбрано 185 деревьев Padus maackii из трех категорий насаждений города Ижевска, которые произрастают в девяти экологических группах по условиям произрастания, ниже представлена характеристика данных условий произрастания. В работе показаны данные мониторинга декоративности коры Padus maackii. Оценка декоративности коры производилась в 2012 и в 2015 гг. в зимнее время, когда данный признак наиболее привлекателен.

Экологическая группа 1a - уличная посадка. Улица со средней интенсивностью движения в центре города, смешанная рядовая посадка в узкую полосу газона вдоль дороги (ул. Коммунаров, 20 деревьев). Ул. Коммунаров находится в центральной части г. Ижевска. Автомагистраль средней интенсивности транспортного потока. Padus maackii произрастает в смешанной рядовой посадке (Betula L. Acer negundo L.). Возраст насаждения Padus maackii более 40 лет. Расстояние между деревьями - 3 м. Ширина полосы газона - 1,5 м. Рядом с насаждением проходит линия электропередач, что ограничивает нормальный рост деревьев. В кронах просматриваются сухие сучья. Насаждения Padus maackii произрастают в затенении от рядом стоящих зданий и от крон рядом растущих деревьев. Исследуемый участок имеет уклон. На стволах имеется много ран от снегоуборочной техники (обдир коры), сухобоины и морозобойные трещины разной величины и глубины. Кроны вытянутые, редкие со следами непрофессиональной обрезки сучьев. Цвет коры у большинства деревьев коричневый, у нескольких деревьев - с небольшим золотистым блеском.

Экологическая группа 1г- уличная посадка. Участок с насаждением Padus maackii по ул. Орджоникидзе находится на выезде из города в зоне завода «Нефтемаш». Автомагистраль на данном участке сильно загружена. В часы пик образуются пробки. Данный участок имеет сильный уклон. Padus maackii произрастает в узкой полосе (1,5 м) газона. Расстояние между деревьями - 3 м. Вдоль посадки проходит линия электропередач. Насаждения в угнетенном состоянии. Стволы имеют в основном темно-оливковый цвет со следами пыли и сажи от транспорта. Кроны периодически обрезаются. Стволы с искривлениями и множеством ран. В кронах просматриваются сухие сучья. По другую сторону пешеходной дорожки имеются рядовые посадки Betula.

Экологическая группа 16 - уличная посадка. Ул. Камбаргская находится в пригородной зоне г. Ижевска. Это продолжение ул. Орджоникидзе, но данный участок автомагистрали разделен широкой полосой с зелеными насаждениями на два полотна дороги с односторонним движением. Транспортный поток средней интенсивности. Исследуемый участок ровный. Padus maackii произрастает в узкой полосе газона вдоль магистрали. Паралельно насаждениям проходит линия электропередач. Кроны периодически обрезаются. Насаждения в хорошем состоянии. Больше половины деревьев имеют стволы с золотистым блеском.

Экологическая группа 1в - рядовая посадка на газоне по ул. Камбаргской. Данная рядовая посадка находится напротив магистральной посадки, описанной выше. Padus maackii произрастает на газоне с рядовой посадкой Betula в шахматном порядке. Между рядами 3 м. Расстояние между деревьями в ряду 5 м. До пешеходной дорожки 5 м. Кроны Betula нависают над кронами Padus maackii и затеняют их. Между Padus maackii встречается Acer negundo. В данной экологической группе большинство деревьев имеют стволы коричневого цвета с золотистым блеском различной интенсивности.

Экологические группы 2a, 2б, 2в, 2г - внутридворовые насаждения. Padus maackii чаще всего встречается в дворовых насаждениях микрорайонов: Буммаш, Автозавод, Металлург. Застройка данных микрорайонов велась в 60-70-е гг. Для исследования были взяты насаждения Padus maackii в дворовых посадках Городка Металлургов, квартал между улицами: Школьная, Фруктовая, 50 лет ВЛКСМ. При обследовании данного квартала выявлено 76 деревьев Padus maackii в одиночных групповых и рядовых посадках. Квартал находится вдали от промышленной зоны. С севера граничит с лесопосадками Pinus L. C востока находятся садовые массивы. По периметру проходит автомагистраль средней интенсивности автопотока. Озеленение данной территории проводилось в 70-80-е гг. Основную массу на- 
саждений занимают насаждения Betula и Populus L. Реже встречаются насаждения разных видов Acer L., Larix Mill., Tilia L., Padus Mill., Sorbus L., Malus L., Prunus cerasus L. Padus maackii присутствует в разных экологических группах: одиночные и групповые посадки в затенении от жилых домов и от крон рядом стоящих деревьев (2a), одиночные и групповые посадки на открытом месте (2б), рядовые посадки вдоль дома (2в), рядовая посадка вдоль межквартального проезда (2г). Padus maackii в групповых и одиночных посадках на открытом месте (2б) имеет декоративные стволы с золотистым блеском. Стволы остальных деревьев имеют золотистый блеск с различной интенсивностью. Чем больше затенение от зданий и от других деревьев, тем меньше интенсивность золотистого блеска.

Экологическая группа 3 - одиночные и групповые посадки в парках и скверах г. Ижевска. Padus maackii в скверах и парках встречается редко. Нами было обследовано 15 скверов и 1 парк города Ижевска. Было выявлено всего 8 деревьев Padus maackii:

1. Сквер у Дворца молодежи на ул. Коммунаров (2 дерева);

2. Сквер имени Дзержинского по ул. Дзержинского (2 дерева);

3. Сквер у Главпочтамта, ул. Кирова (1 дерево);

4. Сквер у бензоколонки по ул. Камбаргской (3 дерева).

Padus maackii произрастает одиночно и в группах с другими деревьями. У всех деревьев красивая ярко-коричневая кора с золотистым блеском.

По полученным данным мониторинга качества декоративности коры Padus maackii были вычислены средние оценки декоративности по каждой экологической группе насаждений (табл. 1).

Таблица 1

Средний балл качества декоративности коры насаждений Padus maackii в различных экологических группах 2012-2015 гг.

\begin{tabular}{|c|c|c|c|c|c|c|c|c|c|c|c|}
\hline \multirow{2}{*}{$\begin{array}{c}\text { Годы } \\
\text { исследования }\end{array}$} & \multicolumn{8}{|c|}{ Средний балл декоративности коры в различных } & \multirow{2}{*}{$\begin{array}{c}\text { Сумма } \\
\text { Общий } \\
\text { средний } \\
\text { баллов }\end{array}$} \\
\cline { 2 - 12 } & $1 \mathrm{a}$ & 16 & 1 валл \\
\hline 2012 & 2,1 & 1,8 & 2.3 & 0,4 & 1,7 & 2,9 & 2,3 & 1,6 & 3,1 & 18,2 & 2,02 \\
\hline 2015 & 0,3 & 1,7 & 2,3 & 0,3 & 1,7 & 3,1 & 2,3 & 1,6 & 3,1 & 16,4 & 1,82 \\
\hline
\end{tabular}

Общий средний балл декоративности коры всех исследуемых насаждений в 2015 г. понизился с 2,02 до 1,82 балла. Самую высокую оценку декоративности коры в 2012 и в 2015 гг. имели одиночные и групповые посадки Padus maackii в скверах города Ижевска (3). Высокую оценку декоративности имели также дворовые насаждения Padus maackii ,произрастающие на открытом месте (2б). Очень низкое качество декоративности в 2015 г. имели уже две экологические группы. Это рядовая посадка в узкую полосу газона вдоль дороги с интенсивным движением (ул. Орджоникидзе, 1г) и рядовая посадка в узкую полосу газона вдоль дороги со средней интенсивностью движения в центре города (ул. Коммунаров, 1a). Данные участки имеют сильный уклон. На снижение декоративности повлияли недостаточное увлажнение и продолжительные высокие температуры в мае и июне 2012-2013 гг. (Архив погоды, 2012-2015). Существенное ухудшение на 1,8 баллов произошло в экологической группе 1а по ул. Коммунаров. Padus maackii произрастает в смешанной рядовой посадке с Betula L. и Acer negundo L. в узкой полосе газона вдоль дороги с уклоном.

Пятибалльная система оценки качества декоративности была разбита на четыре градации: высокое (3-4 балла), среднее (2-2,9 баллов), низкое (1-1,9 баллов), очень низкое (0-0,9 баллов). По полученным группам градаций было подсчитано количество деревьев с высоким, средним и низким качеством декоративности коры Padus maackii. В таблице 2 представлена сравнительная характеристика соотношений деревьев с высоким, средним и низким качеством декоративности коры в разных экологических группах насаждений в 2012 г. и в 2015 г. 
Таблица 2

Соотношение деревьев с высоким, средним и низким качеством декоративности коры в разных экологических группах насаждений в 2012 г. и в 2015 г.

\begin{tabular}{|c|c|c|c|c|c|c|c|c|c|}
\hline \multirow{3}{*}{$\begin{array}{c}\text { Экологические } \\
\text { группы }\end{array}$} & \multicolumn{8}{|c|}{ Градации баллов оценки качества декоративности, баллы } & \multirow{3}{*}{$\begin{array}{c}\text { Всего, } \\
\text { шт. }\end{array}$} \\
\hline & \multicolumn{2}{|c|}{$3,0-4,0$} & \multicolumn{2}{|c|}{$2,0-2,9$} & \multicolumn{2}{|c|}{$1,0-1,9$} & \multicolumn{2}{|c|}{$0-0,9$} & \\
\hline & 2012 г. & $2015 г$. & $2012 \Gamma$. & 2015 г. & $2012 \Gamma$. & 2015 г. & $2012 \Gamma$. & 2015 г. & \\
\hline $1 \mathrm{a}$ & 1 & 0 & 17 & 1 & 2 & 3 & 0 & 16 & \\
\hline 16 & 0 & 0 & 18 & 17 & 16 & 17 & 0 & 0 & \\
\hline $1 \mathrm{~B}$ & 1 & 1 & 26 & 26 & 0 & 0 & 0 & 0 & \\
\hline $1 \Gamma$ & 0 & 0 & 0 & 0 & 7 & 5 & 13 & 15 & \\
\hline $2 a$ & 0 & 0 & 18 & 17 & 19 & 18 & 0 & 2 & \\
\hline 26 & 11 & 11 & 5 & 5 & 1 & 0 & 0 & 1 & \\
\hline $2 \mathrm{~B}$ & 0 & 0 & 14 & 14 & 0 & 0 & 0 & 0 & \\
\hline $2 \Gamma$ & 0 & 0 & 3 & 3 & 5 & 5 & 0 & 0 & \\
\hline 3 & 7 & 7 & 1 & 1 & 0 & 0 & 0 & 0 & \\
\hline Всего, шт. & 20 & 19 & 102 & 84 & 50 & 48 & 13 & 34 & 185 \\
\hline$\%$ & 11 & 10 & 55 & 45 & 27 & 26 & 7 & 18 & \\
\hline
\end{tabular}

По полученным данным (табл. 2) хорошо видно, что количество деревьев с очень низкой оценкой декоративности коры увеличилось в 2015 г. более чем в 2 раза. По сравнению с 2012 г. - с 7 до 18 \%. Увеличение произошло в основном в экологической группе $1 \mathrm{a}$ - с 0 до 16 штук. Это смешанная рядовая посадка в узкую полосу газона вдоль дороги со средней интенсивностью движения в центре города. Данный участок имеет уклон. В 2013 г. было замечено, что листовые пластинки в июне месяце намного мельче, чем у насаждений Padus maackii других экологических групп. В июле месяце почти все листья высохли. На стволах имелось много ран, как экологических (сухобоины и морозобойные трещины), так и от снегоуборочной техники (обдир коры). В 2014 г. у данных деревьев признаков жизни не обнаружено. Количество деревьев, имеющих среднюю оценку, в 2015 г. уменьшилось на $10 \%$. Количество деревьев с высокой оценкой и с низкой оценкой декоративности изменилось незначительно.

В годы исследований были отмечены периоды с экстремальными климатическими условиями. Это недостаточное увлажнение и продолжительные высокие температуры с мая по август 2013 г. и довольно прохладные, с избытком влаги, июль и август 2015 г. В целом данный период характеризуется нестабильностью и не всегда благоприятными условиями для жизнедеятельности растений. Экстремальные климатические условия 2012-2015 гг. больше всего повлияли на качество декоративности коры и другие декоративные качества Padus maackii в экологической группе 1а. Много деревьев погибло. Это рядовая, смешанная с Betula посадка. Насаждения произрастают в узкой полосе газона вдоль дороги со средней интенсивностью движения в центре города. Betula своей поверхностной корневой системой забирает влагу. Участок имеет уклон. Менее всего ухудшение качества декоративных свойств Padus maackii произошло в скверах г. Ижевска. В остальных экологических группах ухудшение качества декоративности коры произошло незначительно. Планирование посадок древесных растений в городской среде должно осуществляться в соответствии с их биологическими особенностями. По шкале отношения древесных пород к влажности почвы она тяготеет к гигромезофитам (Колесников, 1974). Поэтому Padus maackii не следует высаживать на участки с уклоном и в смешанные посадки с деревьями первой величины с поверхностной корневой системой (Betula, Populus). В противном случае декоративность и жизнестойкость насаждений снижается, а это в свою очередь приводит к заболеваниям и преждевременной гибели отдельных деревьев.

\section{ЛИТЕРАТУРА}

Архив погоды в Ижевске. Данные метеостанции (2012-2015 гг.) Ижевск, Россия, (WMO ID) $=28411$.

URL: http:// rp5.ru>Архив_погоды_в_Ижевске (дата обращения 11.12.2018). 
Иншаков Е. М., Сунцова Л. Н. Изучение состояния насаждений Padus maackii и Tilia cordata в условиях техногенного воздействия // Лесной и химический комплексы - проблемы и решения: Сб. ст. по материалам Всерос. науч.-практ. конф. (20-21 ноября 2008 г., Красноярск). - Красноярск, 2009. - Т. 1. - С. 119-122.

Коропачинский И. Ю., Встовская Т. Н. Древесные растения Азиатской России. - Новосибирск, 2002. - С. 335-340.

Колесников А. И. Декоративная дендрология. - М.: Лесная промышленность, 1974. - 703c.

Кузьмина, Н. М., Федоров А. В. Декоративные качества черемухи Маака (Rosaceae) в зависимости от факторов экологической дестабилизации в озеленении г. Ижевска // Роль ботанічних садів і дендропарків у збереженні та збагаченні біологічного різноманіття урбанізованих територій: Матеріали міжнародноі науковоі конференціі. Киев: НЦЕБМ НАН Украины, ПАТ "Віпол", 2013. - С. 97-99.

Сафронова У. А. Комплексная характеристика деревьев черемухи Маака в юго-западной части г. Екатеринбурга // Научное творчество молодежи - лесному комплексу России: матер. V всерос. науч.-техн. конф. Урал. гос. лесотехн. ун.-т. - Екатеринбург, 2009. - С. 130-133.

Семкина Л. А, Макарова О. Б., Яковлева С. В. Состояние зеленых насаждений в г. Свердловске и на некоторых промышленных предприятиях // Экология и интродукция растений на Урале: Сб. науч. трудов. - Свердловск, УрО АН СССР, 1991. - С. 81-93.

Сунцова Л. Н., Иншаков $\boldsymbol{E}$. М. Особенности роста черемухи обыкновенной и Маака в условиях урбанизированной среды города Красноярска // Плодоводство, семеноводство, интродукция древесных растений. 2017. - Т. 20. - C. 182-184.

Усенко Н. В. Деревья, кустарники и лианы Дальнего Востока. - 2-е изд. Перераб. И доп. - Хабаровск, 1984. $-272 \mathrm{c}$ 